\title{
LINX I and II: Lessons Learned and Emerging Questions
}

\author{
Adam S. Wymore*, Bianca M. Rodríguez-Cardona, Allison Herreid and \\ William H. McDowell
}

Department of Natural Resources and the Environment, University of New Hampshire, Durham, NH, United States

\section{OPEN ACCESS}

Edited by:

Gilles Pinay,

National Research Institute of Science and Technology for Environment and Agriculture (IRSTEA), France

Reviewed by:

Nidhi Nagabhatla, United Nations University Institute for Water Environment and Health, Canada Maurice Valett, University of Montana, United States

*Correspondence: Adam S. Wymore adam.wymore@unh.edu

Specialty section:

This article was submitted to

Freshwater Science,

a section of the journal

Frontiers in Environmental Science

Received: 23 May 2019 Accepted: 31 October 2019 Published: 15 November 2019

Citation: Wymore AS, Rodríguez-Cardona BM, Herreid A and McDowell WH (2019) LINX I and II: Lessons Learned and Emerging Questions.

Front. Environ. Sci. 7:181. doi: 10.3389/fenvs.2019.00181
The Lotic Intersite Nitrogen eXperiments (LINX I and II) were a series of replicated in situ manipulations of ${ }^{15} \mathrm{~N}$ across biomes and land-uses designed to assess the factors that control the removal, retention, and ultimate fate of inorganic nitrogen in stream ecosystems. By studying streams at the continental scale, the lessons learned provide some of the best data available to understand the functional role of streams across the landscape, the management implications of nitrogen uptake in streams and rivers, and the value of small streams in elucidating fundamental principles of ecosystem science. Because small streams are characterized by high throughput and low standing stocks of primary producers and stored carbon and nutrients, they provide unique opportunities to assess the fundamental drivers of nitrogen cycling that would be difficult to conduct in other ecosystems. In addition to the water quality implications of understanding controls on nitrogen delivery to downstream systems, LINX I and II also provide unique insights for ecosystem science and stream ecology more broadly. Here we review a series of ecosystem and network-scale lessons that can be inferred from LINX I and II. We then propose three emergent research questions motivated by the LINX projects which are amenable to future continental-scale work. LINX I and II also demonstrate the value of a highly collaborative, distributed approach to ecosystem science that requires each member of the team to conduct a standardized protocol while simultaneously encouraging team member to improve protocols and develop cross-site projects in his or her specific area of expertise.

Keywords: LINX, nitrogen cycling, inorganic nitrogen, headwater streams, river networks, dissolved organic nitrogen

\section{INTRODUCTION}

Due to their position on the landscape, streams, and rivers uniquely connect the terrestrial, sub-surface, groundwater, atmospheric, and ocean components of the earth system. Resulting from the hydrological connectivity among these components, stream and river networks serve as effective transport and erosive systems, aptly expressed by Leopold et al. (1964) as "the gutters down which flow the ruins of continents." At the same time as they act as dominant agents in the Earth's fluvial systems, streams and rivers are also powerful biological reactors in which elemental fluxes are influenced by microbial biogeochemical engines as well as primary production by benthic and planktonic algae or higher plants (Bernhardt et al., 2018). Despite an increased recognition of streams and rivers as both transporters and transformers of terrestrial inputs we are likely underestimating the role that streams and rivers play in 
regulating critical ecosystem and landscape-scale processes such as carbon $(\mathrm{C})$ and nitrogen $(\mathrm{N})$ delivery to the oceans, the venting of greenhouse gases (GHG) to the atmosphere (Cole et al., 2007; Raymond et al., 2013; Hotchkiss et al., 2015) and depositional processes. Perhaps even more important, is the extent to which running waters have been cryptic at the landscape scale due to maps and remote sensing that lack sufficient spatial resolution to quantify them. Recent advances in remote sensing have begun to rectify this situation, however. Initial estimates of the global surface area of streams and rivers derived from scaling properties (Downing et al., 2012) have been revised upward by $44 \%$ using satellite imagery (Allen and Pavelsky, 2018). The combination of more detailed imagery and increased number of studies reporting on gas evasion has led to multiple upward revisions of global evasion fluxes from aquatic environments (Richey et al., 2002; Cole et al., 2007; Raymond et al., 2013; Drake et al., 2018). These examples suggest that stream and river networks play a larger role in global biogeochemical cycles than previously recognized.

One of the best examples of a continental and landscapescale effort to understand stream ecosystems are the LINX (Lotic Intersite Nitrogen eXperiments) projects (Peterson et al., 2001; Mulholland et al., 2008; Hall et al., 2009). Both LINX I and II were motivated by contemporary trends in $\mathrm{N}$ loading to both terrestrial and aquatic ecosystems resulting from fossil fuel combustion, N-fertilizer application, and human and animal waste (Vitousek et al., 1997; Carpenter et al., 1998). These highly collaborative projects sought to understand the controls on inorganic $\mathrm{N}$ cycling in streams across biomes and gradients of land-use through a series of replicated in situ ${ }^{15} \mathrm{~N}$ manipulative experiments. LINX I focused on ammonium $\left(\mathrm{NH}_{4}^{+}\right)$while LINX II focused on nitrate $\left(\mathrm{NO}_{3}^{-}\right)$in order to elucidate the pathways and fate of these forms of dissolved N. Many of the current paradigms through which we view $\mathrm{N}$ cycling in aquatic ecosystems are a direct result of the LINX projects including the heavy focus on inorganic $\mathrm{N}$ (Figure 1). These rich and highquality data sets continue to be explored for novel insights into $\mathrm{N}$ biogeochemistry and the controls on $\mathrm{N}$ uptake and export long after the initial publications from the projects (e.g., Wymore et al., 2016; Marzadri et al., 2017; Grant et al., 2018).

Our objective in this review is to provide both retrospective and forward-looking perspectives inspired by the LINX projects relevant to the broader field of ecosystems ecology. To accomplish this, we first provide a brief overview of LINX I and II and then identify four lessons learned from these projects. We next discuss a series of emerging research questions that result from the advances made during the LINX projects, which are amenable to a next generation of continental-scale investigations.

\section{BRIEF OVERVIEW OF LINX I AND II}

Measured in total kilometers, the global network of streams and rivers is comprised of $\sim 85-90 \%$ low-order streams (1st-3rd; Allan and Castillo, 2008), and these headwaters play a quantitatively significant role in modulating the export of $\mathrm{N}$ to downstream receiving waters (Peterson et al., 2001; Mulholland et al., 2008). Low-order streams can remove upwards of $75 \%$ of the $\mathrm{NO}_{3}^{-}$received from the catchment (Mulholland et al., 2008) with rates of $\mathrm{N}$ removal declining with increases in channel size (Alexander et al., 2000; Peterson et al., 2001). The effectiveness of low-order streams in retaining and removing solutes is a result of their tight connection with the surrounding landscape (Gomi et al., 2002) and a high sediment surface-area to water volume ratio (Alexander et al., 2000; Peterson et al., 2001). Due to the effectiveness of low-order streams in removing $\mathrm{N}$, watershed management is often focused on enhancing removal processes with the objective of improving water quality.

The LINX projects focused primarily on directly measuring in situ rates of ${ }^{15} \mathrm{NH}_{4}^{+}$and ${ }^{15} \mathrm{NO}_{3}^{-}$uptake in lower-order streams and the fate of this labeled $\mathrm{N}$ once it was removed from the water column. By using an identical experimental protocol at each site and consistent approaches to sampling and chemical analysis, the design of these experiments provided a powerful approach to understanding controls on inorganic $\mathrm{N}$ dynamics in streams that spanned North America and the Caribbean. To quantify uptake, both LINX I and II used the framework and metrics of nutrient spiraling (Table 1; Newbold et al., 1981; Stream Solute Workshop, 1990) and tracked both assimilatory and dissimilatory metabolic pathways (e.g., biotic uptake, nitrification, and denitrification) using isotopically labeled N. LINX I included 12 headwater streams across a diverse set of North American biomes and consisted of a continuous ${ }^{15} \mathrm{NH}_{4}^{+}$addition for 6 weeks (Mulholland et al., 2000, 2002; Peterson et al., 2001). This allowed for the quantification of rates of $\mathrm{NH}_{4}^{+}$uptake and nitrification. By tracking the pulse of ${ }^{15} \mathrm{NO}_{3}^{-}$ that was created by nitrification of ${ }^{15} \mathrm{NH}_{4}^{+}$, it also provided rates of $\mathrm{NO}_{3}^{-}$uptake. LINX II included 72 streams that spanned a broad range of watershed land use (urban, agriculture, and forested; Mulholland et al., 2008; Hall et al., 2009) and consisted of short-term ( $24 \mathrm{~h}$ ) additions. The use of an isotopically labeled nutrient added at tracer levels allowed for the analysis of the fate of inorganic $\mathrm{N}$ under ambient conditions. In LINX II, a small mass of very highly enriched ${ }^{15} \mathrm{NO}_{3}^{-}$was added, which allowed for quantification of each nitrogenous end-product, including ${ }^{15} \mathrm{~N}_{2}$, without appreciably changing the background concentrations of $\mathrm{NH}_{4}^{+}$and $\mathrm{NO}_{3}^{-}$. Resulting both directly and indirectly from the success of LINX I and II, is a rich body of literature regarding stream nutrient cycling across biomes at multiple scales, from the reach to entire river network.

\section{Lesson 1: Network Structure Interacts With N Availability to Determine Distribution of Nutrient Retention}

Headwater streams can serve as biogeochemical hotspots due to their high surface-area to volume ratios, which results in increased contact time with the stream benthos. This physical property of headwater streams makes them prime sites for the transformation of inorganic $\mathrm{N}$, frequently resulting in the retention of $>50 \%$ of catchment $\mathrm{N}$ inputs in the form of $\mathrm{NH}_{4}^{+}$ (Peterson et al., 2001). Across the river network for example, uptake length $\left(\mathrm{S}_{\mathrm{w}}\right.$, usually expressed in meters), correlates positively with stream discharge $\left(r^{2}=0.71\right)$. And with the lower discharge that characterizes low-order streams, uptake lengths 


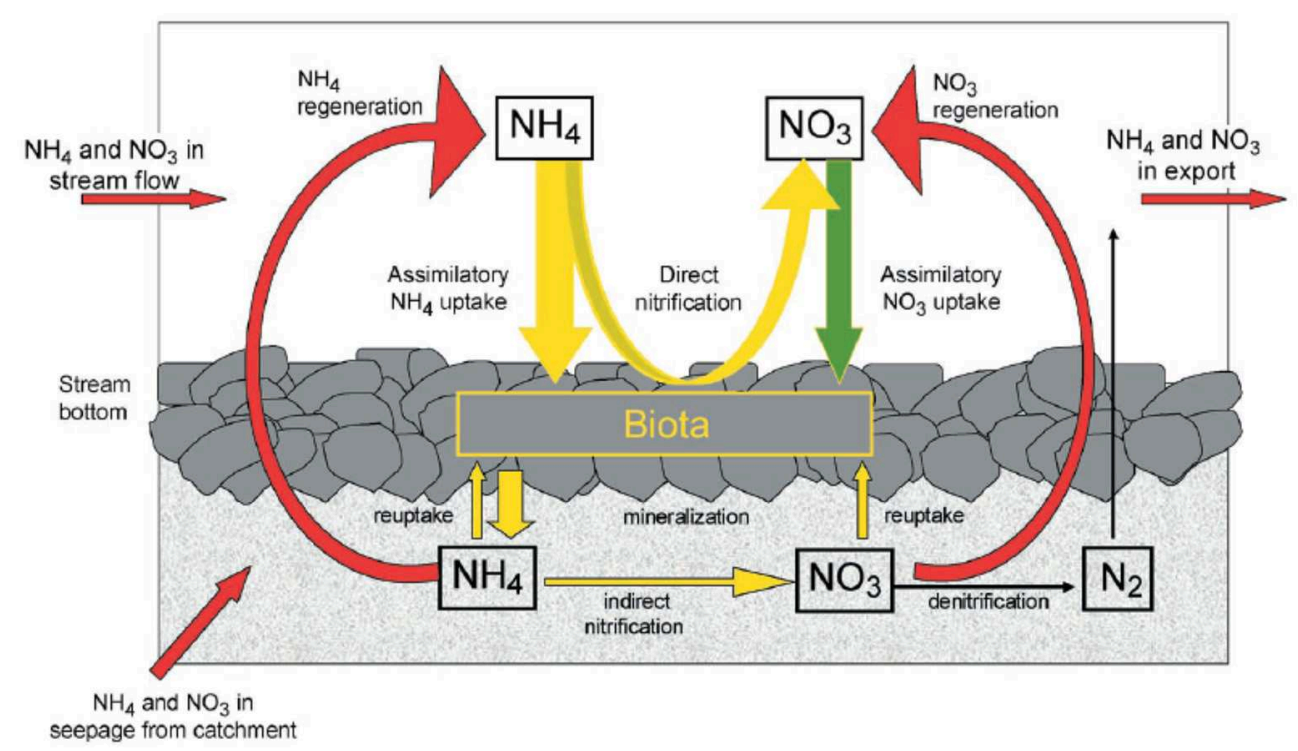

FIGURE 1 | Conceptual model of dissolved inorganic nitrogen cycling in headwater stream ecosystems as originally conceived by Peterson et al. (2001) and through insights gained via LINXI.

TABLE 1 | Summary of LINX I and LINX I| projects along with definitions of key uptake parameters.

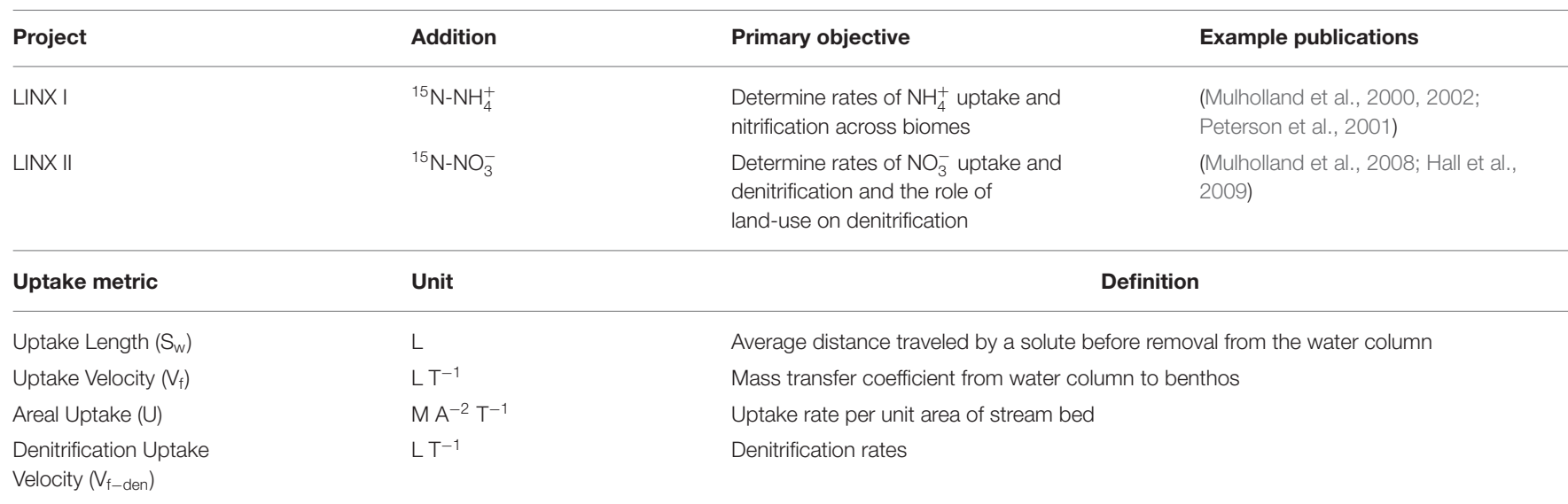

Units of $M$, mass; $A$, area; $L$, length; and $T$, time.

are often shorter in these systems (Peterson et al., 2001). Uptake length has traditionally been defined as the average distance traveled by a solute before removal from the water column and is assumed to result from the utilization of a nutrient by the microbial or autotrophic community (Newbold et al., 1981). Across North America, denitrification accounts for $~ 20-30 \%$ of $\mathrm{NO}_{3}^{-}$uptake and nitrification accounts for $16 \%$ of the total $\mathrm{NH}_{4}^{+}$ removal in headwater streams (Peterson et al., 2001; Mulholland et al., 2008).

One of the major findings from LINX II was that when $\mathrm{NO}_{3}^{-}$ was abundant at the watershed scale, the proportion of $\mathrm{NO}_{3}^{-}$ removed via uptake declined across the network (Mulholland et al., 2008; Figure 2). Increased loading of $\mathrm{NO}_{3}^{-}$results in increases of both assimilatory uptake and denitrification, but river basin $\mathrm{NO}_{3}^{-}$exports increase disproportionately relative to inputs. Put another way, as environmental degradation and impact accelerate and watershed inputs of $\mathrm{N}$ increase, the ability of streams to remove added $\mathrm{N}$ becomes proportionately less effective even though stream water concentrations of inorganic $\mathrm{N}$ continue to increase. This observation holds across streams of various size and ultimately results in nearly all watershed-inputs of inorganic $\mathrm{N}$ being exported to downstream receiving ecosystems under very high loading. These results directly point to the ability of headwater stream ecosystems to affect the distribution of reactive $\mathrm{N}$ at the landscape and network scale and the observed saturation in $\mathrm{NO}_{3}^{-}$removal rates indicate that there are upper limits to this critical ecosystem service.

Understanding saturation also requires recognition that the various processes within the $\mathrm{N}$ cycle saturate at different 


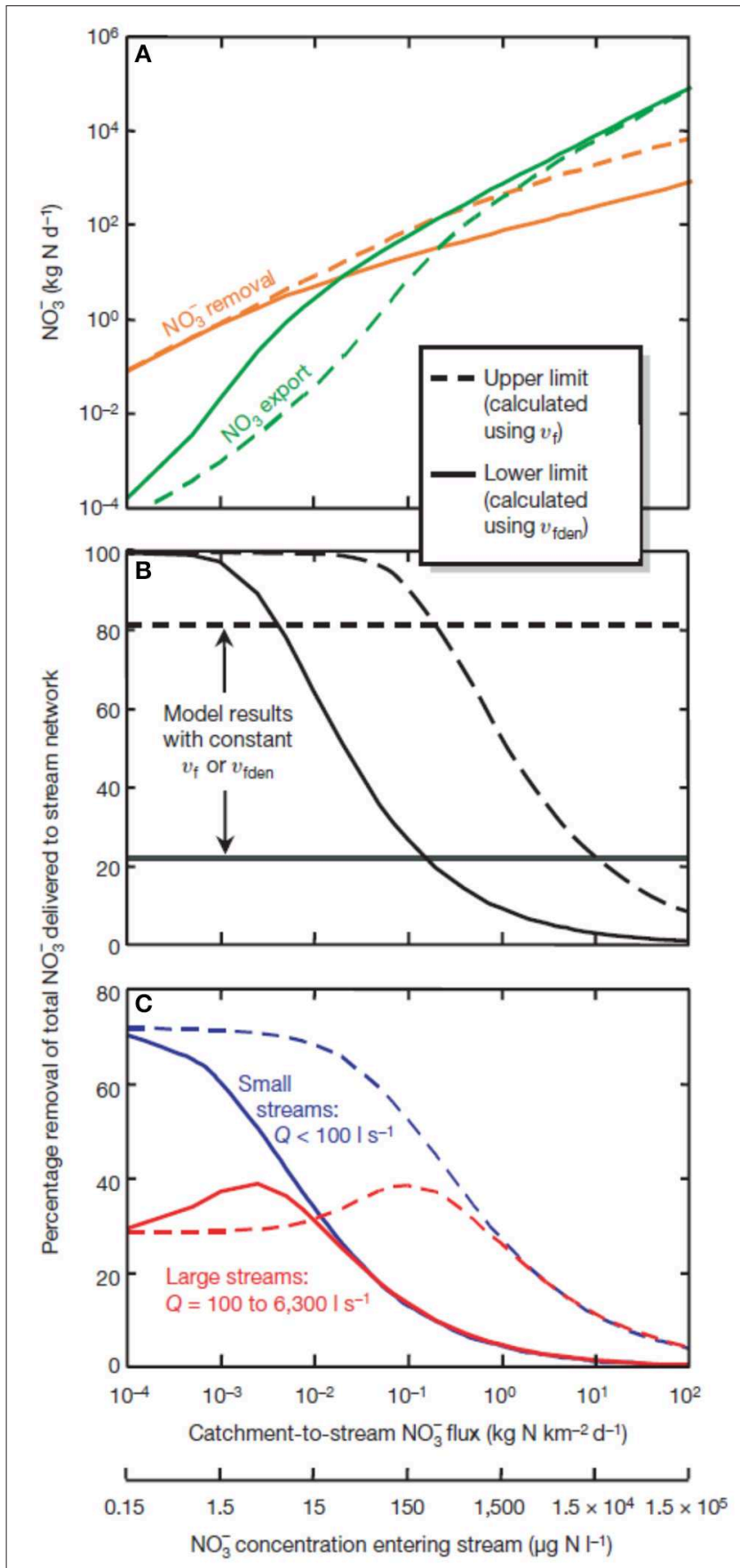

FIGURE 2 | Modeled data from the LINX || project showing (A) the relationship between removal and export of $\mathrm{NO}_{3}^{-}$against $\mathrm{NO}_{3}^{-}$loading rates (as both catchment to stream flux and as stream water concentration); (B) $\mathrm{NO}_{3}^{-}$ removal due to biological processes with curves reflecting model results when uptake velocity $\left(V_{f}\right)$ and uptake velocity due to denitrification $\left(V_{\text {fden }}\right)$ vary with $\mathrm{NO}_{3}^{-}$concentrations; (C) patterns of $\mathrm{NO}_{3}^{-}$removal shown for small and large streams [curves similar to those shown in (B)]. See Mulholland et al. (2008) for additional discussion.

points along trajectories of $\mathrm{N}$ loading. For example, assimilatory demand for $\mathrm{N}$ saturates prior to denitrification, which in turn, saturates prior to nitrification (Bernot and Dodds, 2005). While streams may be active sites of $\mathrm{N}$ uptake at the landscape scale, these different points of saturation have the potential to exacerbate concentrations of $\mathrm{NO}_{3}^{-}$and downstream exports (Bernot and Dodds, 2005). Points of saturation may also be influenced by other factors including the availability of carbon (Johnson et al., 2009), light (Lowe et al., 1986) and phosphorus, which can become limiting to primary productivity in high-N streams (Earl et al., 2006). Saturation also occurs at the network scale whereby rates of nutrient supply outpace demand and rates of removal. This "network-scale saturation" (Wollheim et al., 2018) is evident in declining effectiveness of $\mathrm{N}$ removal mechanisms in headwaters, and subsequent transport of large quantities of $\mathrm{NO}_{3}^{-}$downstream (Hall et al., 2009; Mulholland et al., 2009). As $\mathrm{NO}_{3}^{-}$concentrations increase in small streams, the resulting increase in $\mathrm{NO}_{3}^{-}$export shifts the site of most $\mathrm{N}$ removal downstream to larger rivers. This indicates that $\mathrm{N}$ inputs and associated removal processes can be highly separated in space and time creating a mosaic of $\mathrm{N}$ processing rates within and across river networks. It should be noted that saturation of $\mathrm{N}$ removal can still occur in higher-order rivers resulting in little to no removal/processing at the network scale (Wollheim et al., 2018). While headwaters prove to be a highly effective component of the river network (Bernot and Dodds, 2005), ultimately it is the whole stream network that drives $\mathrm{N}$ removal based on landscape-scale inputs and heterogeneity in the demand for $\mathrm{N}$ by in-stream biota at the network-scale.

This lesson in particular has major implications for watershed management and water quality. The widespread conversion of landscapes for intensive agricultural production can be expected to contribute even more to the excessive loading of nutrients to streams and rivers and the eutrophication of coastal ecosystems (e.g., National Research Council, 2000; Rabalais, 2002). Yet evidence clearly indicates that intentional efforts to control the loading of biologically available forms of $\mathrm{N}$ to aquatic ecosystem are highly effective, including reduction in the application of $\mathrm{N}$-rich fertilizers (McIssac et al., 2001) and restoration of riparian buffers (Vellidis et al., 2003).

\section{Lesson 2: N Biogeochemistry Is Driven by Energetic Constraints}

Although low-order streams can be highly effective at nutrient removal, rates of inorganic $\mathrm{N}$ uptake also show a high degree of inter-site variability with rates spanning orders of magnitude. Measured as uptake velocity $\left(V_{f}\right.$ : length time ${ }^{-1}$ ) to account for the influence of variation in physical parameters among streams, rates of $\mathrm{NH}_{4}^{+}$removal from the water column are often higher than those of $\mathrm{NO}_{3}^{-}\left[\mathrm{NH}_{4}^{+}: 1.8-42 \mathrm{~mm} / \mathrm{min}\right.$ (Peterson et al., 2001); $\mathrm{NO}_{3}^{-}$: 0.024-17.9 $\mathrm{mm} / \mathrm{min}$ (Hall et al., 2009)]. Because $\mathrm{NH}_{4}^{+}$ can serve as an energy source in the process of nitrification, as well as a form of $\mathrm{N}$ that can be readily assimilated, it is typically the form of $\mathrm{N}$ found at lowest concentrations in running waters. Although $\mathrm{NH}_{4}^{+}$uptake due to nitrification accounted for approximately one-fifth to a third of the total $\mathrm{NH}_{4}^{+}$uptake across all LINX sites (Peterson et al., 2001), in the tropical streams of Puerto Rico nitrification approached half of total $\mathrm{NH}_{4}^{+}$removal from the water column (Merriam et al., 2002). 
Higher rates of $\mathrm{NH}_{4}^{+}$than $\mathrm{NO}_{3}^{-}$uptake are often attributed to the fact that $\mathrm{NH}_{4}^{+}$uptake requires fewer reduction steps prior to assimilation providing a more energetically favorable source of N (Webster et al., 2003; O'Brien and Dodds, 2010). It is important to acknowledge that differences in $V_{f}$ can be misleading when making conclusions about energetically favorable biogeochemical pathways. $V_{f}$ is often calculated as the quotient of areal uptake and concentration $\left(V_{f}=\mathrm{U} / \mathrm{C}\right)$. A more parsimonious explanation for the consistently lower $V_{f}$ values of $\mathrm{NO}_{3}^{-}$relative to $\mathrm{NH}_{4}^{+}$is that $\mathrm{NO}_{3}^{-}$is often found in greater concentrations across aquatic ecosystems. Inferences regarding $V_{f}$ must therefore be treated with caution.

Changes in riparian canopy cover associated with land use directly influence rates of gross primary productivity (GPP) and indirectly, $\mathrm{NO}_{3}^{-}$uptake. Higher rates of GPP are associated with shorter $S_{w}$ and increased $V_{f}$ demonstrating the role of autotrophs in regulating $\mathrm{NO}_{3}^{-}$uptake since total $\mathrm{NO}_{3}^{-}$uptake showed no clear patterns with respiration (Mulholland et al., 2000, 2008, 2009; Hall et al., 2009). Rates of GPP in turn were influenced by land use where agricultural and urban streams, with less canopy cover, promoted greater GPP, compared to references sites that were more shaded (Hall et al., 2009). In contrast to total $\mathrm{NO}_{3}^{-}$ uptake, rates of denitrification $\left(V_{f-\text { den }}\right)$ were related to ecosystem respiration (ER), which tends to decrease DO concentrations and thereby increases the likelihood that metabolic demand for an alternative electron acceptor like $\mathrm{NO}_{3}^{-}$will be significant (Mulholland et al., 2008, 2009). The strong relationship between denitrification and ER in streams where surface water is largely oxic suggests that low DO hot spots associated with higher overall respiration are common and result in increased rates of denitrification at the whole-reach scale (Mulholland et al., 2009).

Uptake metrics also differed with land-use where nitrate areal uptake (U; mass area ${ }^{-1}$ time $^{-1}$ ) was greater in agricultural and urban sites compared to reference sites (Mulholland et al., 2008; Hall et al., 2009). However, unlike areal uptake, $\mathrm{NO}_{3}^{-} V_{f}$ was not associated with variation in land use. Rather, $V_{f}$ decreased with increasing $\mathrm{NO}_{3}^{-}$concentrations, indicating a decline in the effectiveness of the microbial community at removing and retaining $\mathrm{NO}_{3}^{-}$with increasing $\mathrm{NO}_{3}^{-}$concentrations. This pattern was persistent across multiple sites (Mulholland et al., 2008; Hall et al., 2009).

\section{Lesson 3: In-stream Processes Alter the Form and Abundance of the Reactive N Pool}

Changes to the composition of the reactive $\mathrm{N}$ pool due to nutrient loading may have profound biogeochemical implications for aquatic ecosystems and communities. One unanticipated yet significant discovery of LINX I and II was the incorporation of both isotopically labeled ${ }^{15} \mathrm{NH}_{4}^{+}$and ${ }^{15} \mathrm{NO}_{3}^{-}$into dissolved organic $\mathrm{N}$ (DON). Across forested watersheds, for example, labeled $\mathrm{NH}_{4}^{+}$accounted for $\sim 4-10 \%$ of exported DON (Ashkenas et al., 2004). These values likely represent an underestimate however, due to a sampling protocol that only targeted the end of the experimental manipulation and no cumulative or temporal measurements of DON production via this autochthonous pathway were accounted for. In LINX II, labeled DON was found in 26 of 36 streams and from across different land-use types (Johnson et al., 2013) after only $24 \mathrm{~h}$ of ${ }^{15} \mathrm{NO}_{3}^{-}$addition. These results demonstrate that in-stream biogeochemical processes can alter the form and abundance of the reactive $\mathrm{N}$ pool, and the cycling of DIN "back" to DON suggests feedbacks between the inorganic and organic fractions of the total dissolved $\mathrm{N}$ pool which have received relatively little attention in the literature. And while terrestrially derived and $\mathrm{N}$-rich dissolved organic matter has been shown to serve as an important nutrient source to aquatic microbial communities (Johnson et al., 2013; Wymore et al., 2015; Kissman et al., 2017), it is not clear how this newly synthesized DON may influence other biogeochemical reactions. If the DON that results from these pathways differs in bioavailability, sorption capacity, or overall reactivity relative to the originally labeled $\mathrm{NH}_{4}^{+}$or $\mathrm{NO}_{3}^{-}$, then we can expect other biogeochemical consequences including altered rates of mineralization and nitrification which may be important at the network scale.

\section{Lesson 4: The Influence of Streams on the Earth System}

Due to their position in the landscape, streams connect multiple components of the earth's surface and biosphere. This includes critical landscape-stream-atmosphere interactions that influence GHG emissions. As both nitrification and denitrification are potential sources of $\mathrm{N}_{2} \mathrm{O}$ to the atmosphere, quantifying GHG emissions from stream networks is critical for accurate predictions and models. This is especially important given the global warming potential of $\mathrm{N}_{2} \mathrm{O}\left(275 \times\right.$ that of $\left.\mathrm{CO}_{2}\right)$ and the recent upward revision to the total surface area of streams and rivers on the earth's surface (Allen and Pavelsky, 2018). The role of nitrification in the production of $\mathrm{N}_{2} \mathrm{O}$ in lotic and freshwater ecosystems however, remains unresolved (Seitzinger and Kroeze, 1998; Harrison and Matson, 2003; Beaulieu et al., 2008, 2011). While we recognize the role of denitrification in producing $\mathrm{N}_{2} \mathrm{O}$, we choose to focus this lesson on some of the unique insights gained from LINX I and II regarding nitrification and its potential links to GHG production.

The high rates of nitrification often reported through nutrient addition experiments in headwater streams (Peterson et al., 2001; Beaulieu et al., 2008; Koenig et al., 2017b), suggest a potentially substantial production of $\mathrm{N}_{2} \mathrm{O}$ that has not been clearly quantified. Ammonium is rapidly transformed in streams through nitrification, which results in the appearance of isotopically labeled $\mathrm{NO}_{3}^{-}$from addition of ${ }^{15} \mathrm{NH}_{4}^{+}$(Mulholland et al., 2000) and at the continental scale, nitrification in small streams accounts for $20-30 \%$ of total $\mathrm{NH}_{4}^{+}$uptake (Peterson et al., 2001). A great deal of uncertainty remains however, regarding the connection between nitrification and $\mathrm{N}_{2} \mathrm{O}$ production and in-stream vs. groundwater processes in generating the $\mathrm{N}_{2} \mathrm{O}$ found in streams. Across streams with relatively high $\mathrm{NO}_{3}^{-}$concentrations in the midwestern US, rates of nitrification are on par with those of denitrification, yet $\mathrm{N}_{2} \mathrm{O}$ yield was more associated with rates of denitrification and concentrations of $\mathrm{NO}_{3}^{-}$(presumably from the agricultural 
landscape) rather than nitrification (Beaulieu et al., 2008). In the assessment of $\mathrm{N}_{2} \mathrm{O}$ production via denitrification in LINX II however, in-stream denitrification only accounted for $26 \%$ of the total emitted $\mathrm{N}_{2} \mathrm{O}$ and the vast majority of $\mathrm{NO}_{3}^{-}$that was denitrified was lost as $\mathrm{N}_{2}$ rather than $\mathrm{N}_{2} \mathrm{O}$ (Beaulieu et al., 2011). It is theoretically possible for nitrification to account for $>50 \%$ of $\mathrm{N}_{2} \mathrm{O}$ emission from headwater streams (Beaulieu et al., 2011). Current reports from the Intergovernmental Panel on Climate Change (IPCC, 2018) assume that nitrification produces twice as much $\mathrm{N}_{2} \mathrm{O}$ relative to denitrification in streams and rivers globally; thus, quantifying and understanding the spatial and temporal variability in $\mathrm{N}_{2} \mathrm{O}$ yield via nitrification from streams and rivers is essential.

Certain dogma regarding the controls on nitrification are not particularly well supported by field data. For example, it is commonly accepted that heterotrophs outcompete nitrifiers for $\mathrm{NH}_{4}^{+}$in the presence of available carbon (Bernhardt and Likens, 2002; Strauss and Lamberti, 2002; Strauss et al., 2002; Dodds et al., 2004; Starry et al., 2005). Contrary examples exist however, that challenge this "heterotrophs first" perspective and the role of dissolved organic carbon in regulating rates of nitrification, raising questions regarding the distribution of nitrification hotspots across the landscape. Streams draining deciduous forests for example, can have very high rates of nitrification even though organic matter inputs remain high (Richey et al., 1985; Mulholland et al., 2000) while in agricultural streams nitrification rates were positively associated with sediment carbon content (Beaulieu et al., 2011). Furthermore, small headwater streams in the Luquillo Mountains of Puerto Rico, which are generally considered energy rather than $\mathrm{N}$ limited, show a high degree of variability in the proportion of $\mathrm{NH}_{4}^{+}$uptake accounted for by nitrification with rates varying both temporally and spatially (Koenig et al., 2017b).

\section{EMERGING RESEARCH QUESTIONS AMENABLE TO THE NEXT GENERATION OF CONTINENTAL-SCALE INVESTIGATIONS}

Although the LINX projects provide substantial insights into $\mathrm{N}$ cycling, numerous research questions can be identified regarding other controlling processes on the $\mathrm{N}$ cycle within river networks. Here we identify three emerging questions (EQs) which offer opportunity to understand $\mathrm{N}$ cycling dynamics in greater detail and which are amenable to continental-scale investigation similar to LINX I and II. We assert that these questions, which are well-suited to whole-ecosystem experimental studies in streams, are of broader ecological significance. They would illuminate fundamental aspects of the $\mathrm{N}$ cycle and ecosystem function which are not readily addressed with whole-system manipulations in other environments such as lakes or forests.

\section{EQ 1: How Does Variability in DOM Composition Influence N Processing?}

Both the concentration and composition of dissolved organic matter (DOM) influence $\mathrm{N}$-cycling processes in aquatic ecosystems such as biotic uptake and nitrification (Strauss and

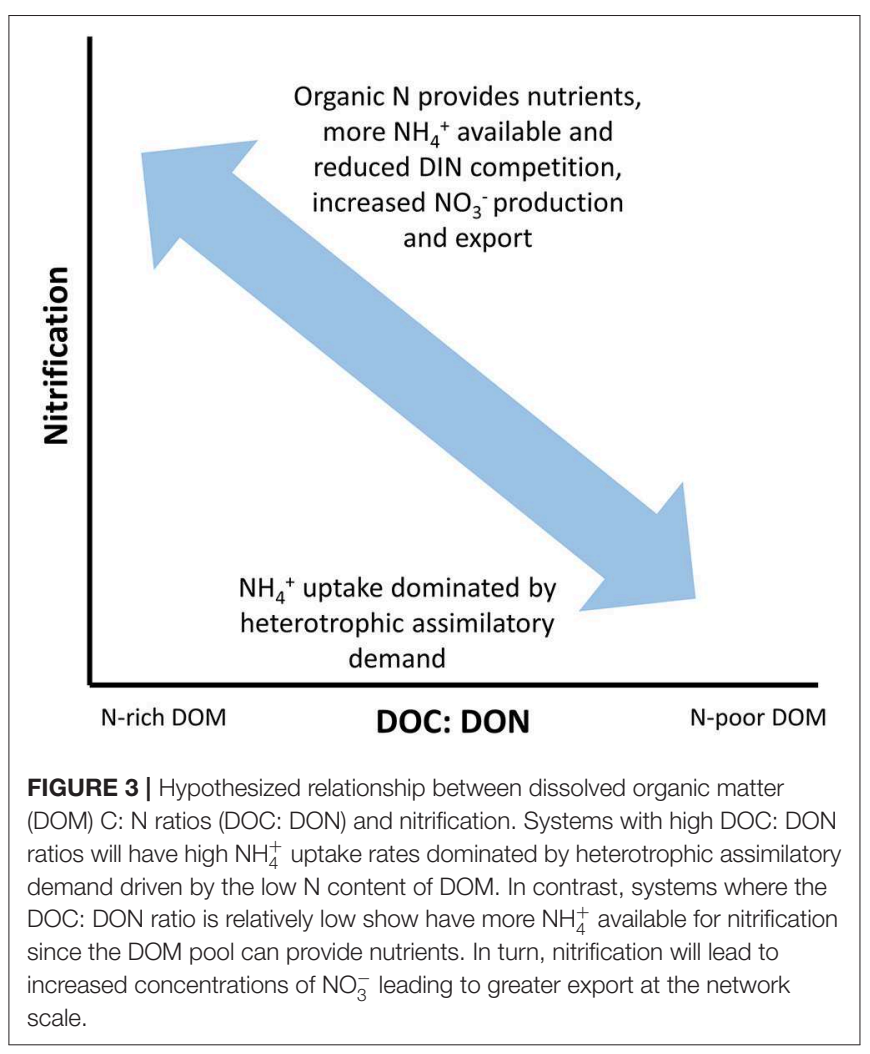

Lamberti, 2002; Strauss et al., 2002; Bernhardt and McDowell, 2008; Fork and Heffernan, 2014). It is thus essential to consider the over-arching hypothesis that DOM composition, and not just quantity, influences $\mathrm{N}$ cycling processes. Connecting the composition of DOM to other biogeochemical cycles is challenging due to the inherent molecular diversity of DOM, with hundreds of thousands of recognized compounds found in environmental samples (e.g., Kellerman et al., 2014). This limits the prospect of manipulative studies to understand how the diversity of DOM drives biogeochemical cycles. Previous studies have rightfully simplified this challenge via the addition of single compounds (e.g., glucose, acetate; Thouin et al., 2009) or single sources (e.g., leaf litter leachate: Strauss et al., 2002; Bernhardt and McDowell, 2008). Inferences regarding the effects of DOM composition on the $\mathrm{N}$ cycle and associated gas fluxes are thus limited in scope and must be interpreted with caution.

One of the most direct and simple assessments of DOM composition and potential bioavailability is through its bulk C: $\mathrm{N}$ ratio (i.e., DOC: DON). We can hypothesize, for example, that rates of nitrification should be higher in those systems in which the DOM has lower DOC: DON ratios due to the availability of organic $\mathrm{N}$ to satisfy nutrient demands (Figure 3). This has been demonstrated in laboratory incubations by altering the ratio of L-lysine acetate and sodium acetate (Strauss et al., 2002). Abundant and available DON should reduce competition between heterotrophs and nitrifiers for $\mathrm{NH}_{4}^{+}$, which should maintain higher rates of nitrification. In turn, this would increase $\mathrm{NO}_{3}^{-}$production and potentially $\mathrm{NO}_{3}^{-}$exports at the network scale if nutrient demand is satisfied. 
Certain forms of DON may provide a source of $\mathrm{NH}_{4}^{+}$through depolymerization and mineralization that could increase rates of nitrification. Similarly, N availability through the DOM pool should reduce rates of assimilatory demand for $\mathrm{NO}_{3}^{-}$affecting rates of denitrification. Techniques such as ${ }^{15} \mathrm{~N}$ isotopic pool dilutions could be used to assess protein depolymerization through gross amino acid production (Wanek et al., 2010). This type of tracer enrichment has been used successfully in soil and litter-bag studies to ascertain whether depolymerization or mineralization is the rate-limiting step in the $\mathrm{N}$ cycle (Schimel and Bennett, 2004; Wanek et al., 2010; van Groenigen et al., 2015). Here we suggest that these pool dilution techniques could be used to assess how the production of inorganic $\mathrm{N}$ varies across environmental and disturbance gradients and with changes in DOM composition. Establishing these relationships would provide fundamental insights into how $\mathrm{C}$ and $\mathrm{N}$ cycles are linked across aquatic ecosystems and various sources of organic matter. As far as we know, these relationships have not been investigated in streams and rivers at any scale including in situ manipulations or at the landscape scale.

Recent advances in high-resolution analytical chemistry techniques (e.g., pyrolysis GC/MS, Fourier Transformation Ion Cyclotron Resonance MS) provide powerful insights into how the chemistry and molecular structure of DOM vary over space and time and can provide insight into how variability in DOM composition relates to the cycling of inorganic $\mathrm{N}$. Relevant DOM variability can be described at relatively coarse levels of resolution such as the relative abundance of $\mathrm{N}$ containing compounds (e.g., Lusk and Toor, 2016; Pisani et al., 2017) or how the 3-D molecular structure determines the availability of $\mathrm{N}$ and the energy expenditure required for acquiring nutrients from the ambient pool of DOM. For example, some sources of $\mathrm{N}$ can be more easily accessed such as terminal amine groups, while others may exist in more protected and unavailable forms such as heterocyclic organic molecules that stabilize the $\mathrm{N}$ through multiple covalent bonds. Sampling efforts across broad environmental gradients and from multiple sources of organic matter that enter aquatic ecosystems would allow for the assessment of how variability in DOM composition relates to $\mathrm{N}$ cycling processes as well as the role of landscape characteristics and climatic variability in influencing biogeochemical interactions.

Inferences made by comparing DOM composition to rates of $\mathrm{N}$ cycling must be treated with caution, however. Comparing gross rates of $\mathrm{N}$ cycling (made possible through isotopic labels) to the net effects of metabolic processes on DOM composition is effectively a comparison of a given reaction rate to the substrate that did not participate in the reaction. This may explain why metrics of DOM composition can at times fail to provide little predictive capacity of nutrient uptake metrics (e.g., RodríguezCardona et al., 2016). Connecting DOM source to in-stream reactions offers one solution to this experimental limitation. A detailed assessment of the fate of various DOM sources that are rapidly utilized, and do not appear in the DOM pool at measurable levels, is central to a better understanding of DOM-N interactions.

\section{EQ 2: How Do We Disentangle $\mathrm{N}_{2} \mathrm{O}$ Coming From Nitrification vs. Nitrifier-Denitrification or Coupled Nitrification-Denitrification? What Portion of $\mathrm{NH}_{4}^{+}$Uptake Is Accounted for by Anammox, Which Removes DIN With No $\mathrm{N}_{2} \mathrm{O}$ Production?}

The approximate doubling of reactive $\mathrm{N}$ due to human activities has resulted in a corresponding increase in riverine $\mathrm{N}$ loading (Galloway et al., 2004; Green et al., 2004). This increase in $\mathrm{N}$ loading has resulted in an increase in $\mathrm{N}_{2} \mathrm{O}$ emission rates from inland waters, with estimates ranging over orders of magnitude from 0.01 to $2.1 \mathrm{Tg} \mathrm{N}_{2} \mathrm{O}-\mathrm{N} \mathrm{yr}^{-1}$ (Seitzinger and Kroeze, 1998; Cole and Caraco, 2001; Kroeze et al., 2005; Beaulieu et al., 2011; Syakila and Kroeze, 2011; Hu et al., 2016; Maavara et al., 2019). These highly variable numbers suggest that riverine fluxes of $\mathrm{N}_{2} \mathrm{O}$ could account for anywhere between 0.1 and $31 \%$ of the anthropogenic production of $\mathrm{N}_{2} \mathrm{O}$ from land (Ravishankara et al., 2009) although it should be noted that the most recent estimates place global fluxes on the lower end of the reported range $\mathrm{Hu}$ et al., 2016; Maavara et al., 2019; Webb et al., 2019). Unlike soils, however, small changes in the molar ratio of $\mathrm{N}_{2}: \mathrm{N}_{2} \mathrm{O}$ in resident pools from inland waters could result in large changes in greenhouse gas production. Molar ratios of $\mathrm{N}_{2}: \mathrm{N}_{2} \mathrm{O}$ in soils are $\sim 1: 1$, but in freshwater ecosystems the ratio is $\sim 99: 1$, and only small changes in the molar ratio of $\mathrm{N}_{2}: \mathrm{N}_{2} \mathrm{O}$ are needed to create large absolute changes in the amount of $\mathrm{N}_{2} \mathrm{O}$ produced (Beaulieu et al., 2011).

Given the projected increase in N loading to fluvial ecosystems and uncertainties surrounding global emission estimates, there is a clear need to improve understanding of $\mathrm{N}_{2} \mathrm{O}$ dynamics to more accurately model and predict emissions from streams and rivers (Dumont et al., 2005; Boyer et al., 2006; Hu et al., 2016; Quick et al., 2019). Refining emission estimates is critical for informing possible mitigation strategies in response to increasing anthropogenic $\mathrm{N}_{2} \mathrm{O}$ emissions particularly those regarding the balance between nitrification and denitrification as drivers of $\mathrm{N}_{2} \mathrm{O}$ production (Maavara et al., 2019; Quick et al., 2019).

Many $\mathrm{N}_{2} \mathrm{O}$ producing pathways have similar yet not identical environmental optima (Quick et al., 2019), making it difficult to interpret correlations between predictor variables and concentrations and fluxes of $\mathrm{N}_{2} \mathrm{O}$. As a result, it is difficult to confidently assign certain processes to observed patterns. For example, nitrifier-denitrification (the oxidation of ammonia to nitrite followed by the reduction of nitrite to nitric oxide, $\mathrm{N}_{2} \mathrm{O}$, and $\mathrm{N}_{2}$; Wrage et al., 2001) is enhanced under both low concentrations of dissolved organic carbon (similar to nitrification) and low concentrations of dissolved oxygen (similar to denitrification) (Wrage et al., 2001). Experiments using isotopic tracers similar to LINX could help elucidate dominant pathways; however, challenges exist with this approach. For example, added ${ }^{15} \mathrm{NH}_{4}$ could be nitrified, producing either $\mathrm{NO}_{3}^{-}$ or $\mathrm{N}_{2} \mathrm{O}$ via the oxidation of hydroxylamine $\left(\mathrm{NH}_{2} \mathrm{OH}\right)$. These products of nitrification could then be subsequently denitrified to $\mathrm{N}_{2} \mathrm{O}$ or $\mathrm{N}_{2}$, or reduced back to $\mathrm{NH}_{4}^{+}$via DNRA (Dissimilatory 
nitrate reduction to ammonium), which represents another pathway of $\mathrm{N}_{2} \mathrm{O}$ consumption (Sanford et al., 2012). Due to the many fates of $\mathrm{NH}_{4}^{+}$and the fact that $\mathrm{N}$-cycling processes are strongly mediated by microbial activity, experiments using ${ }^{15} \mathrm{NH}_{4}$ will need to be paired with characterization of microbial communities and enzyme activity assays to help disentangle the dominant pathways responsible for producing $\mathrm{N}_{2} \mathrm{O}$.

In addition to disentangling dominant $\mathrm{N}_{2} \mathrm{O}$ production and consumption pathways, future work should investigate the importance of anammox in fluvial ecosystems. Anammox, the anaerobic oxidation of $\mathrm{NH}_{4}^{+}$coupled to $\mathrm{NO}_{3}^{-}$reduction, results in $\mathrm{N}_{2}$ and may play an important role as an $\mathrm{N}$ loss pathway (Devol, 2003). The anammox process as currently understood involves no, or at least lower, $\mathrm{N}_{2} \mathrm{O}$ emission when compared with denitrification and nitrification (Kampschreur et al., 2008). While anammox accounts for over $50 \%$ of gaseous $\mathrm{N}$ loss as $\mathrm{N}_{2}$ in marine ecosystems, the importance of this process in freshwater ecosystems has received less attention (Devol, 2003; Zhu et al., 2010). Anammox hotspots are recognized to occur at terrestrial-aquatic interfaces (Zhu et al., 2010, 2013) and oxicanoxic boundaries (Zhu et al., 2015). These observations suggest that headwater streams that are connected to wetlands or have a high degree of connectivity between surface and hyporheic water may serve as important control points (sensu stricto Bernhardt et al., 2017) for anammox at the landscape scale. The ratio of anammox to nitrification and/or denitrification will influence the molar ratio of $\mathrm{N}_{2}: \mathrm{N}_{2} \mathrm{O}$ and ultimately the net fluxes of $\mathrm{N}_{2} \mathrm{O}$ from freshwater systems. Environmental conditions (e.g., oxygen availability, temperature) and the influence of land use in loading $\mathrm{N}$ to freshwater ecosystems play a large role in determining which $\mathrm{N}$-cycling pathways are dominant at a given place and time.

\section{EQ 3: How Do Concentrations and Fluxes of Nitrogen Respond to Increased Runoff From Watersheds?}

Concentration-Discharge (C-Q) relationships are a fundamental tool for understanding the sources and transport of material from watersheds (Chorover et al., 2017). C-Q analyses are particularly useful as they reflect the multivariate landscape-scale integration of the effects of source, hydrology, biogeochemical cycles, and state-factors including watershed size, vegetation, climate, soil, and lithology (e.g., Wymore et al., 2017). Although this approach has been used to understand the various controls on solutes and sediments across diverse environments (e.g., Johnson et al., 1969; Godsey et al., 2009; Herndon et al., 2018; Rose et al., 2018; Wymore et al., 2019), less attention has been given to the mobilization and transport of $\mathrm{N}$ and the implications for $\mathrm{N}$ cycling processes. And while certain forms of dissolved $\mathrm{N}$ (e.g., $\mathrm{NO}_{3}^{-}, \mathrm{DON}$ ) often do not appear to respond to changes in discharge across a broad range of flow conditions (Wymore et al., 2017; Coble et al., 2018), concentrations of $\mathrm{NO}_{3}^{-}$do respond to changes in flow during individual storm events (Koenig et al., 2017a; Bernal et al., 2019) even when the overall relationship between concentration and discharge is weak. A detailed examination of how the different forms of dissolved $\mathrm{N}$ respond to changes in flow across diverse environments would help to elucidate the relative contribution

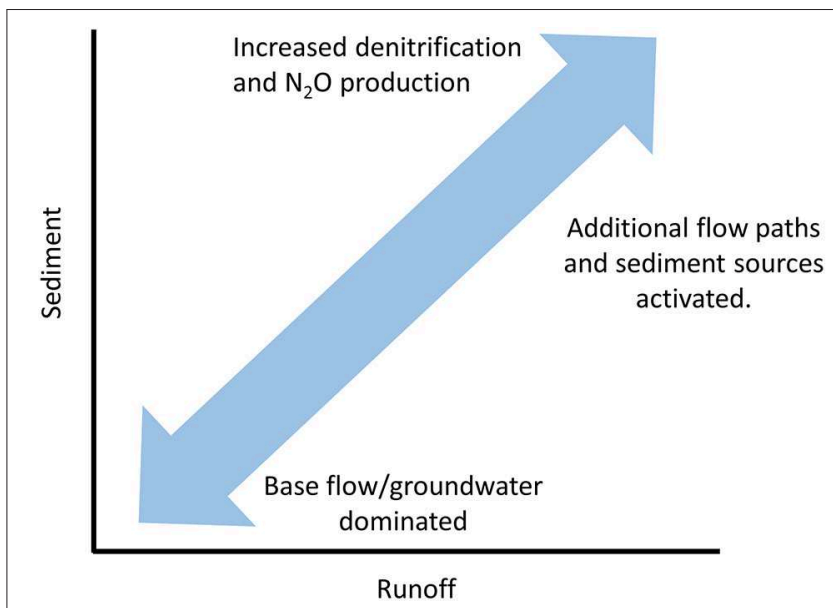

FIGURE 4 | A hypothetical relationship between sediment and runoff and rates of denitrification and $\mathrm{N}_{2} \mathrm{O}$ production associated with sediment load. Under elevated runoff, sediment concentrations increase due to the activation of addition flow paths and sources from the hillslope and watershed. The additional production of sediment will increase the abundance of anoxic microsites and conditions for denitrification and potentially $\mathrm{N}_{2} \mathrm{O}$ production. Note that this simplified model assumes no change in the size distribution of sediments which could influence rates of biogeochemical reactions.

of in situ-, hillslope-, and groundwater-based biogeochemical processes to fluvial exports of $\mathrm{N}$.

It is widely recognized that high flow events are responsible for the majority of solute and sediment exports to fluvial networks and downstream ecosystems (Hilton et al., 2008; Raymond and Saiers, 2010; Inamdar et al., 2017). Both solutes and sediment often display hysteresis at the event scale, defined as differences in concentration at the same interval of discharge on both the rising and falling limbs of the hydrograph. This results in distinct "hysteresis loops" and the directionality of the loop provides insight into where material is stored within watersheds and the role of water residence time in mobilizing material to the stream channel (Gellis, 2013; Koenig et al., 2017a; Rose et al., 2018; Wymore et al., 2019). For example, it is inferred from clockwise hysteresis that sources are proximal to the stream channel and rapidly mobilized, whereas counterclockwise hysteresis reflects sources that are proximal to the stream channel with slow travel times or sources that are distal (i.e., further up a flow path) from the point of sampling.

Understanding the controls on the mobilization and transport of sediment to the stream networks would provide essential insights in the contribution of storms and extreme events to the export of $\mathrm{N}$ and in-stream dynamics that connect sediment production to $\mathrm{NO}_{3}^{-}$biogeochemistry. Denitrification correlates positively with the concentration of suspended sediments (Liu et al., 2013) due to an abundance of anoxic microsites which facilitate the reduction of $\mathrm{NO}_{3}^{-}$(Quick et al., 2019). The relationship between sediments and $\mathrm{NO}_{3}^{-}$biogeochemistry may have significant implications for $\mathrm{NO}_{3}^{-}$removal from the river network and $\mathrm{N}_{2} \mathrm{O}$ production (Figure 4). Sediments often display a strong flushing response to changes in discharge (e.g., Wymore et al., 2019) and typically show a distinct clockwise hysteresis (Gellis, 2013; Aich et al., 2014; Clark et al., 2017; Rose 
et al., 2018). In addition to this strong response to precipitation and runoff, sediments and particle size distribution can also vary across sites as a function of lithology (e.g., Larsen, 1997; Pike et al., 2010; Phillips and Jerolmack, 2016) with storm magnitude influencing the heterogeneity of the transported particle load. This may be of importance in those environments that transport disproportionately large quantities of sediment such as the tropics (Schlesinger and Bernhardt, 2013) while also maintaining relatively high levels of $\mathrm{NO}_{3}^{-}$due to nitrification (Koenig et al., 2017b).

\section{CONCLUSIONS}

Efforts of both LINX I and LINX II demonstrate the immense value of headwater streams at the network scale through the ecosystem services which they provide that directly benefit society. Historic destruction of streams too small to warrant a blue line on the map has likely had major effects of watershed $\mathrm{N}$-flux in many regions. Efforts to study, protect, restore, and highlight the functionality of headwater streams are critical to manage pollution and enhance water quality in downstream navigable waters as mandated by the Clean Water Act (Alexander et al., 2007). Understanding how headwater streams and navigable water are physically, chemically, and biologically connected is essential for establishing the jurisdiction and effectiveness of the Clean Water Act.

The lessons learned and emerging questions resulting from the LINX projects encourage a more holistic view of the $\mathrm{N}$ cycle at the river network and landscape scale. For example, many standard $\mathrm{N}$ cycling diagrams within textbooks often omit DON. The LINX projects clearly demonstrate the de novo production of DON resulting from the addition of tracer levels of DIN and recent work points to a meaningful ecological role of DON in aquatic environments (Wymore et al., 2015; Kissman et al., 2017). The field of aquatic biogeochemistry is thus poised to fully integrate the three main components of the total dissolved nitrogen pool: DON, $\mathrm{NH}_{4}^{+}$, and $\mathrm{NO}_{3}^{-}$. To fully understand the biogeochemical and microbial controls on $\mathrm{N}$ cycling, we must consider in greater detail other reactions within the $\mathrm{N}$ cycle that produce and remove DIN (Burgin and Hamilton, 2007).

The innumerable insights offered through the LINX projects are in part due to the high-quality nature of the data sets, achieved through rigorous QA/QC protocols and thoughtful data curation. While the burgeoning domain of network science (e.g., National Ecological Observatory Network) offers the possibility of unique insights across both space and time, the LINX projects remind us of how a relatively low investment of research funds can result in high productivity and a high scientific output relative to investment. Such efforts can result in numerous unintended and unanticipated discoveries as new perspectives and questions are brought to bear. For example,

\section{REFERENCES}

Aich, V., Zimmermann, A., and Elsenbeer, H. (2014). Quantification and interpretation of suspended-sediment discharge hysteresis patterns: how much data do we need? Catena 122, 120-129. doi: 10.1016/j.catena.2014.06.020 the LINX II data set continues to offer fertile ground for discovery regarding freshwater ecosystems even though the projects formally ended $\sim 12-20$ years ago (e.g., Wymore et al., 2016; Grant et al., 2018). One of the essential features of the LINX projects was that the fundamental experimental platform was consistent and focused on collecting the broad suite of data needed to answer a set of specific questions about stream ecosystem function. This experimental design resulted in the ability to answer a wide range of questions (Mulholland et al., 2008; Grant et al., 2018) from a single data set. It also relied on understanding reach and network dynamics, something that is conspicuously absent from the single-point approach of measuring water quality exemplified by NEON (McDowell, 2015). Development of future insights into stream nutrient dynamics at the continental scale must include both the watershed and network context to make meaningful contributions. Finally, in addition to the longterm productivity resulting from the initial investments, the LINX projects provided a unique and collaborative training ground for countless undergraduates, graduate students, and post-doctoral researchers. Collaboration among senior personnel set the stage for the collegial and inclusive environment that has proven essential for the development of the next generation of environmental scientists and ecosystem ecologists (Goring et al., 2014).

\section{AUTHOR CONTRIBUTIONS}

All authors contributed to the development of ideas presented in the manuscript and contributed to the writing.

\section{FUNDING}

The LINX I project was supported by NSF grants DEB-9628860, DEB-9810222, and OPP-9615949. The LINX II project was originally funded by U.S. National Science Foundation (NSF) grant DEB-0111410 and multiple NSF Long Term Ecological Research (LTER) grants. Funding for manuscript preparation was provided by NSF DEB-1556603 (Deciphering Dissolved Organic Nitrogen), the StreamPulse project (EF-1442444), and the New Hampshire Agricultural Experiment Station. This is Scientific Contribution 2819. This work was supported by the USDA National Institute of Food and Agriculture (McIntire-Stennis), project accession 1006760 .

\section{ACKNOWLEDGMENTS}

We are grateful to all of the participants in the LINX I and II projects who conceived, implemented, and conducted the field work. We also thank the reviewers whose comments have greatly improved this manuscript.

Alexander, R. B., Boyer, E. W., Smith, R. A., Schwartz, G. E., and Moore, R. B. (2007). The role of headwater streams in downstream water quality. J. Am. Water Res. Assoc. 43, 41-59. doi: 10.1111/j.1752-1688.2007.00005.x

Alexander, R. B., Smith, R. A., and Schwartz, G. E. (2000). Effects of stream channel size on the delivery of nitrogen to 
the Gulf of Mexico. Nature 403, 758-761. doi: 10.1038/350 01562

Allan, J. D., and Castillo, M. M. (2008). Stream Ecology: Structure and Function of Running Waters, 2nd Edn. Dordrecht: Springer.

Allen, G. H., and Pavelsky, T. M. (2018). Global extent of rivers and streams. Science 361, 585-588. doi: 10.1126/science.aat0636

Ashkenas, L. R., Johnson, S. L., Gregory, S. V., Tank, J. L., and Wollheim, W. M. (2004). A stable isotope tracer study of nitrogen uptake and transformation in an old-growth forest stream. Ecology 85, 1725-1739. doi: 10.1890/03-0032

Beaulieu, J. J., Arango, C. P., Hamilton, S. K., and Tank, J. L. (2008). The production and emission of nitrous oxide from headwater streams in the Midwestern United States. Global Change Biol. 14, 878-894. doi: 10.1111/j.1365-2486.2007.01485.x

Beaulieu, J. J., Tank, J. L., Hamilton, S. K., Wollheim, W. M., Hall, R. O. Jr., Mulholland, P. J., et al. (2011). Nitrous oxide emissions from denitrification in stream and river networks. Proc. Natl. Acad. Sci. U.S.A. 108, 214-219. doi: 10.1073/pnas.1011464108

Bernal, S., Lupon, A., Wollheim, W. M., Sabater, F., Poblador, S., and Martí, E. (2019). Supply, demand, and in-stream retention of dissolved organic carbon and nitrate during storms in Mediterranean forested headwater streams. Front. Environ. Sci. 7:60. doi: 10.3389/fenvs.2019.00060

Bernhardt, E. S., Blaszczak, J. R., Ficken, C. D., Fork, M. L., Kaiser, K. E., and Seybold, E. C. (2017). Control points in ecosystems: moving beyond the hot spot hot moment concept. Ecosystems 30, 665-682. doi: 10.1007/s10021-016-0103-y

Bernhardt, E. S., Heffernan, J. B., Grimm, N. B., Stanley, E. H., Harvey, J. W., Arroita, M., et al. (2018). The metabolic regimes of flowing waters. Limnol. Oceanogr. 63, S99-S118. doi: 10.1002/lno.10726

Bernhardt, E. S., and Likens, G. E. (2002). Dissolved organic carbon enrichment alters nitrogen dynamics in a forest stream. Ecology 83, 1689-1700. doi: 10.1890/0012-9658(2002)083[1689:DOCEAN]2.0.CO;2

Bernhardt, E. S., and McDowell, W. H. (2008). Twenty years apart: comparison of DOM uptake during leaf leachate releases to Hubbard Brook Valley streams in 1979 versus 2000. J. Geophys. Res. 113:G03032. doi: 10.1029/2007JG000618

Bernot, M. J., and Dodds, W. K. (2005). Nitrogen retention, removal, and saturation in lotic ecosystems. Ecosystems 8, 442-453. doi: 10.1007/s10021-003-0143-y

Boyer, E. W., Howarth, R. W., Galloway, J. N., Dentener, F. J., Green, P. A., and Vörösmarty, C. J. (2006). Riverine nitrogen export from the continents to the coasts. Global Biogeochem. Cycles 20, 1-91. doi: 10.1029/2005GB002537

Burgin, A. J., and Hamilton, S. K. (2007). Have we overemphasized the role of denitrification in aquatic ecosystems? A review of nitrate removal pathways. Front. Ecol. Environ. 5, 89-96. doi: 10.1890/1540-9295(2007)5[89:HWOTRO]2.0.CO;2

Carpenter, S. R., Caraco, N. F., Correll, D. L., Howarth, R. W., Sharpley, A. N., and Smith, V. H. (1998). Nonpoint pollution of surface waters with phosphorous and nitrogen. Ecol. Appl. 8, 559-568. doi: 10.1890/1051-0761(1998)008[0559:NPOSWW]2.0.CO;2

Chorover, J., Derry, L. A., and McDowell, W. H. (2017). Concentrationdischarge relations in the critical zone: implications for resolving critical zone structure, function and evolution. Water Resour. Res. 53, 8654-8659. doi: 10.1002/2017WR021111

Clark, K. E., Shanley, J. B., Scholl, M. A., Perdrial, N., Perdrial, J. N., Plante, A. F., et al. (2017). Tropical river suspended sediment and solute dynamics in storms during an extreme drought. Water Resour. Res. 53, 3695-3712. doi: 10.1002/2016WR019737

Coble, A. A., Wymore, A. S., Shattuck, M. D., Potter, J. D., and McDowell, W. H. (2018). Long-term trends in solute concentrations and fluxes from a suburban watershed: evaluating effects of 100-year flood events. J. Geophys. Res. 123, 3072-3087.

Cole, J. J., and Caraco, N. F. (2001). Emissions of nitrous oxide $\left(\mathrm{N}_{2} \mathrm{O}\right)$ from a tidal, freshwater river, the Hudson, River, New York. Environ. Sci. Technol. 35, 991-996. doi: 10.1021/es0015848

Cole, J. J., Prairie, Y. T., Caraco, N. F., McDowell, W. H., Tranvik, L. J., Striegl, R. G., et al. (2007). Plumbing the global carbon cycle: integrating inland waters into the terrestrial carbon budget. Ecosystems 10, 172-185. doi: 10.1007/s10021-006-9013-8
Devol, A. H. (2003). Denitrification, anammox, and $\mathrm{N}_{2}$ production in marine sediments. Ann. Rev. Marine Sci. 7, 403-423. doi: 10.1146/annurev-marine-010213-135040

Dodds, W. K., Marti, E., Tank, J. L., Pontius, J., Hamilton, S. K., Grimm, N. B., et al. (2004). Carbon and nitrogen stoichiometry and nitrogen cycling rates in streams. Oecologia. 140, 458-467. doi: 10.1007/s00442-004-1599-y

Downing, J. A., Cole, J. J., Duarte, C. M., Middelburg, J. J., Melack, J. M., Prairie, Y. T., et al. (2012). Global abundance and size distribution of streams and rivers. Inland Waters 2, 229-236. doi: 10.5268/IW-2.4.502

Drake, T. W., Raymond, P. A., and Spencer, R. G. M. (2018). Terrestrial carbon inputs to inland waters: a current synthesis of estimates and uncertainty. Limnol. Oceanogr. Lett. 3, 132-142. doi: 10.1002/lol2.10055

Dumont, E., Harrison, J. A., Kroeze, C., Bakker, E. J., and Seitzinger, S. P. (2005). Global distribution and sources of dissolved inorganic nitrogen export to the coastal zone: results from a spatially explicit, global model. Glob. Biogeochem. Cycles 19:GB4S02. doi: 10.1029/2005GB002488

Earl, S. R., Valett, H. M., and Webster, J. R. (2006). Nitrogen saturation in stream ecosystems. Ecology 87, 3140-3151. doi: 10.1890/0012-9658(2006)87[3140:NSISE]2.0.CO;2

Fork, M. L., and Heffernan, J. B. (2014). Direct and indirect effects of dissolved organic matter source and concentration on denitrification in northern Florida rivers. Ecosystems 17, 14-28. doi: 10.1007/s10021-013-9705-9

Galloway, J. N., Dentener, F. J., Capone, D. G., Boyer, E. W., Howarth, R. W., Seitzinger, S. P., et al. (2004). Nitrogen cycle: past, present, and future. Biogeochemistry 70, 153-226. doi: 10.1007/s10533-004-0370-0

Gellis, A. C. (2013). Factors influencing storm-generated suspended-sediment concentrations and loads in four basins of contrasting land use, humid-tropical Puerto Rico. Catena 104, 39-57. doi: 10.1016/j.catena.2012.10.018

Godsey, S. E., Kirchner, J. W., and Clow, D. W. (2009). Concentration-discharge relationships reflect chemostatic characteristics of US catchments, Hydrol. Proces. 23, 1844-1864. doi: 10.1002/hyp.7315

Gomi, T., Sidle, R. C., and Richardson, J. S. (2002). Understanding processes and downstream linkages of headwater systems. Bioscience 52, 905-916. doi: 10.1641/0006-3568(2002)052 [0905:UPADLO]2.0.CO;2

Goring, S. J., Weathers, K. C., Dodds, W. K., Soranno, P. A., Sweet, L. C., Cheruvelil, K. S., et al. (2014). Improving the culture of interdisciplinary collaboration in ecology by expanding measures of success. Front. Ecol. Environ. 12, 39-47. doi: 10.1890/120370

Grant, S. B., Azizian, M., Cook, P., Boano, F., and Rippy, M. A. (2018). Factoring stream turbulence into global assessments of nitrogen pollution. Science 359, 1266-1269. doi: 10.1126/science.aap8074

Green, P. A., Vörösmarty, C. J., Maybeck, M., Galloway, J. N., Peterson, B. J., and Boyer, E. W. (2004). Pre-industrial and contemporary fluxes of nitrogen through rivers: a global assessment based on typology. Biogeochemistry 68, 71-105. doi: 10.1023/B:BIOG.0000025742.82155.92

Hall, R. O. Jr., Tank, J. L., Sobota, D. J., Mulholland, P. J., O’Brien, J. M., Dodds, W. K., et al. (2009). Nitrate removal in stream ecosystems measured by $15 \mathrm{~N}$ addition experiments: total uptake. Limnol. Oceanogr. 54, 653-665. doi: $10.4319 /$ lo.2009.54.3.0653

Harrison, J., and Matson, P. (2003). Patterns and controls of nitrous oxide emissions from waters draining a subtropical agricultural valley. Glob. Biogeochem. Cycles 17:1080. doi: 10.1029/2002GB001991

Herndon, E. M., Steinhoefel, G., Dere, A. L. D., and Sullivan, P. L. (2018). Perennial flow through convergent hillslopes explains chemodynamic behavior in a shale headwater catchment. Chem. Geol. 493, 413-425. doi: 10.1016/j.chemgeo.2018.06.019

Hilton, R. G., Galy, A., Hovius, N., Chen, M.-C., Horng, M.-J., and Chen, H. (2008). Tropical-cyclone-driven erosion of the terrestrial-biosphere from mountains. Nat. Geosci. 1, 759-612. doi: 10.1038/ngeo333

Hotchkiss, E. R., Hall R. O. Jr., Sponseller, R. A., Butman, D., Klaminder J., Laudon $\mathrm{H}$., et al. (2015). Sources of and processes controlling $\mathrm{CO}_{2}$ emissions changes with the size of streams and rivers. Nat. Geosci. 8, 696-699.

Hu, M., Chen, D., and Dahlgren, R. A. (2016). Modeling nitrous oxide emission from rivers: a global assessment. Glob. Change Biol. 22, 3566-3582. doi: $10.1111 / \mathrm{gcb} .13351$

Inamdar, S., Shanely, J. B., and McDowell, W. H. (2017). Aquatic ecosystems in a changing climate. EOS 98. doi: 10.1029/2017EO076549 
IPCC (2018). "Global warming of $1.5^{\circ} \mathrm{C}$," in An IPCC Special Report on the Impacts of Global Warming of $1.5^{\circ} \mathrm{C}$ Above Pre-industrial Levels and Related Global Greenhouse Gas Emission Pathways, in the Context of Strengthening the Global Response to the Threat of Climate Change, Sustainable Development, and Efforts to Eradicate Poverty. Geneva: World Meteorological Organization.

Johnson, L. T., Tank, J. L., and Arango, C. P. (2009). The effect of land use on dissolved organic carbon and nitrogen uptake in streams. Freshw. Biol. 54, 2335-2350. doi: 10.1111/j.1365-2427.2009.02261.x

Johnson, L. T., Tank, J. L., Hall, R. O., Mulholland, P. J., Hamilton, S. K., Valett, H. M., et al. (2013). Quantifying the production of dissolved organic nitrogen in headwater streams using $15 \mathrm{~N}$ tracer additions. Limnol. Oceanogr. 58, 1271-1285. doi: 10.4319/lo.2013.58.4.1271

Johnson, N. M., Likens, G. E., Bormann, F. H., Fisher, D. W., and Pierce, R. S. (1969). A working model for the variation in stream water chemistry at the Hubbard Brook Experimental Forest, New Hampshire. Water Resour. Res. 5, 1353-1363. doi: 10.1029/WR005i006p01353

Kampschreur, M. J., van der Star, W. R. L., Wielders, H. A., Mulder, J. W., Jetten, M. S. M., and van Loosdrecht, M. C. M. (2008). Dynamics of nitric oxide and nitrous oxide emission during full-scale reject water treatment. Water Res. 42, 812-826. doi: 10.1016/j.watres.2007.08.022

Kellerman, A. M., Dittmar, T., Kothawala, D. N., and Tranvik, L. J. (2014). Chemodiversity of dissolved organic matter in lakes driven by climate and hydrology. Nat. Commun. 5:3804. doi: 10.1038/ncomms4804

Kissman, C. E. H., Williamson, C. E., Rose, K. C., and Saros, J. E. (2017). Nutrients associated with terrestrial dissolved organic matter drives changes in zooplankton: phytoplankton biomass ratios in an alpine lake. Freshw. Biol, 62, 40-51. doi: 10.1111/fwb.12847

Koenig, L. E., Shattuck, M. D., Snyder, L. E., Potter, J. D., and McDowell, W. H. (2017a). Deconstructing the effects of flow on DOC, nitrate, and major ion interactions using a high-frequency aquatic sensor network. Water Resour. Res. 53, 10655-10673. doi: 10.1002/2017WR020739

Koenig, L. E., Song, C., Wollheim, W. M., Rüegg, J., and McDowell, W. H. (2017b). Nitrification increases nitrogen export from a tropical river network. Freshw. Sci. 36, 698-712. doi: 10.1086/694906

Kroeze, C., Dumont, E., and Seitzinger, S. P. (2005). New estimates of global emissions of $\mathrm{N} 2 \mathrm{O}$ from rivers and estuaries. Environ. Sci, 2, 159-165. doi: $10.1080 / 15693430500384671$

Larsen, M. C. (1997). Tropical geomorphology and geomorphicwork-a study of geomorphic processes and sediment and water budgets in montane humidtropical forested and developed watersheds, Puerto Rico ( $\mathrm{PhD}$ dissertation). University of Colorado, Boulder, CO, United States.

Leopold, L. B., Wolman, M. G., and Miller, J. R. (1964). Fluvial Processes in Geomorphology. San Francisco, CA: W. H. Freeman.

Liu, T., Xia, X., Liu, S., Mou, X., and Qiu, Y. (2013). Acceleration of denitrification in turbid rivers due to denitrification occurring on suspended sediments in oxic waters. Environ. Sci. Technol. 47, 4053-4061. doi: 10.1021/es304504m

Lowe, R. L., Golladay, S. W., and Webster, J. R. (1986). Periphyton response to nutrient manipulation in streams draining clearcut and forested watersheds. J. North Am. Benthol. Soc. 5, 221-229. doi: 10.2307/1467709

Lusk, M. G., and Toor, G. S. (2016). Biodegradability and molecular composition of dissolved organic nitrogen in urban stormwater runoff and outflow water from a stormwater retention pond. Environ. Sci. Technol. 50, 3391-3398. doi: 10.1021/acs.est.5b05714

Maavara, T., Lauerwald, R., Laruelle, G. G., Akbarzadeh, Z., Bouskill, N. J., Cappellen, P. V., et al. (2019). Nitrous oxide emissions from inland waters: are IPCC estimates too high? Global Change Biol. 25, 473-488. doi: $10.1111 / \mathrm{gcb} .14504$

Marzadri, A., Dee, M. M., Tonina, D., Bellin, A., and Tank, J. L. (2017). Role of surface and subsurface processes in scaling $\mathrm{N}_{2} \mathrm{O}$ emissions along riverine networks. Proc. Natl. Acad. Sci. U.S.A. 144, 4330-4335. doi: $10.1073 /$ pnas. 1617454114

McDowell, W. H. (2015). NEON and STREON: opportunities and challenges for the aquatic sciences. Freshw. Sci. 34, 386-339. doi: 10.1086/679489

McIssac, G. F., David, M. B., Gertner, G. Z., and Goolsby, D. A. (2001). Net anthropogenic $\mathrm{N}$ inputs to the Mississippi River basin and nitrate flux to the Gulf of Mexico. Nature 414, 166-167. doi: 10.1038/35102672

Merriam, J. L., McDowell, W. H., Tank, J. L., Wollheim, W. M., Crenshaw, C. L., and Johnson, S. L. (2002). Characterizing nitrogen dynamics, retention and transport in a tropical rainforest stream using an in situ15N addition. Freshw. Biol. 47, 143-160. doi: 10.1046/j.1365-2427.2002.00785.x

Mulholland, P. J., Hall, R. O., Sobota, D. J., Dodds, W. K., Findlay, S. E. G., Grimm, N. B., et al. (2009). Nitrate removal in stream ecosystems measured by $15 \mathrm{~N}$ addition experiments: denitrification. Limnol. Oceanogr. 54, 666-680. doi: 10.4319/lo.2009.54.3.0666

Mulholland, P. J., Helton, A. M., Poole, G. C., Hall, R. O., Hamilton, S. K., Peterson, B. J., et al. (2008). Stream denitrification across biomes and its response to anthropogenic nitrate loading. Nature 452, 202-205. doi: 10.1038/nature 06686

Mulholland, P. J., Tank, J. L., Sanzone, D. M., Wollheim, W. M., Peterson, B. J., Webster, J. R., et al. (2000). Nitrogen cycling in a forest stream determined by a $15 \mathrm{~N}$ tracer addition. Ecol. Monogr. 70, 471-493. doi: 10.1890/0012-9615(2000)070[0471:NCIAFS]2.0.CO;2

Mulholland, P. J., Tank, J. L., Webster, J. R., Bowden, W. B., Dodds, W. K., Gregory, S. V., et al. (2002). Can uptake length in streams be determined by nutrient addition experiments? results from an interbiome comparison study. J. North Am. Benthol. Soc. 21:544. doi: 10.2307/1468429

National Research Council (2000). Clean Coastal Waters: Understanding and Reducing the Effects of Nutrient Pollution. Washington, DC: National Academy Press.

Newbold, J. D., Elwood, J. W., O’Neill, R. V., and Winkle, W. V. (1981). Measuring nutrient spiralling in streams. Can. J. Fish. Aquat. Sci. 38, 860-863. doi: 10.1139/f81-114

O'Brien, J. M., and Dodds, W. K. (2010). Saturation of $\mathrm{NO}_{3}^{-}$uptake in prairie streams as a function of acute and chronic $\mathrm{N}$ exposure. J. N. Am. Benthol. Soc. 29, 627-635. doi: 10.1899/09-021.1

Peterson, B. J., Wollheim, W. M., Mulholland, P. J., Webster, J. R., Meyer, J. L., Tank, J. L., et al. (2001). Control of nitrogen export from watersheds by headwater streams. Science 292, 86-90. doi: 10.1126/science.1056874

Phillips, C. B., and Jerolmack, D. J. (2016). Self-organization of river channels as a critical filter on climate signals. Science 352, 694-697. doi: 10.1126/science.aad3348

Pike, A. S., Scatena, F. N., and Wohl, E. E. (2010). Lithological and fluvial control on the geomorphology of tropical montane stream channels in Puerto Rico. Earth Surf. Process. Landforms 35, 1402-1417. doi: 10.1002/esp. 1978

Pisani, O., Boyer, J. N., Podgorski, D. C., Thomas, C. R., Coley, T., and Jaffé, R. (2017). Molecular composition and bioavailability of dissolved organic nitrogen in a lake flow-influenced river in south Florida, USA. Aquat. Sci. 79, 1-18. doi: 10.1007/s00027-017-0540-5

Quick, A. M., Reeder, W. J., Farrell, T. B., Feris, K. P., and Benner, S. G. (2019). Nitrous oxide from streams and rivers: a review of primary biogeochemical pathways and environmental variables. Earth Sci. Rev. 191, 224-262. doi: 10.1016/j.earscirev.2019.02.021

Rabalais, N. N. (2002). Nitrogen in aquatic ecosystems. J. Hum. Environ. 31, 102-112. doi: 10.1579/0044-7447-31.2.102

Ravishankara, A. R., Daniel, J. S., and Portman, R. W. (2009). Nitrous oxide (N2O): the dominant ozone-depleting substance emitted in the $21^{\text {st }}$ century. Science 326, 123-125. doi: 10.1126/science.1176985

Raymond, P. A., Hartmann, J., Lauerwald, R., Sobek, S., McDonald, C., Hoover, M., et al. (2013). Global carbon dioxide emissions from inland waters. Nature 503, 355. doi: $10.1038 /$ nature 12760

Raymond, P. A., and Saiers, J. E. (2010). Event controlled DOC export from forested watersheds. Biogeochemistry 100, 197-209. doi: $10.1007 /$ s10533-010-9416-7

Richey, J. E., Melack, J. M., Aufdenkampe, A. K., Ballester, V. M., and Hess, L. L. (2002). Outgassing from Amazonian rivers and wetlands as a large tropical source of atmospheric CO2. Nature 416, 617-620. doi: 10.1038/416617a

Richey, J. S., McDowell, W. H., and Likens, G. E. (1985). Nitrogen transformations in a small mountain stream. Hydrobiologia 124, 129-139. doi: $10.1007 /$ bfo0006795

Rodríguez-Cardona, B., Wymore, A. S., and McDowell, W. H. (2016). DOC: NO3ratios control NO3- uptake in forested headwater streams. J. Geophys. Res. 121, 205-217. doi: 10.1002/2015JG003146

Rose, L. A., Karwan, D. L., and Godsey, S. E. (2018). Concentration-discharge relationships describe solute and sediment mobilization, reaction, and transport at event and longer timescales. Hydrol. Process. 32, 2829-2844. doi: 10.1002/hyp. 13235 
Sanford, R. A., Wagner, D. D., Wu, Q., Chee-Sanford, J. C., Thomas, S. H., CruzGarcia, C., et al. (2012). Unexpected nondenitrifier nitrous oxide reductase gene diversity and abundance in soils. Proc. Natl. Acad. Sci. U.S.A. 109, 19709-19714. doi: $10.1073 /$ pnas.1211238109

Schimel, J. P., and Bennett, J. (2004). Nitrogen mineralization: challenges of a changing paradigm. Ecology 85, 591-602. doi: 10.1890/03-8002

Schlesinger, W. H., and Bernhardt, E. S. (2013). Biogeochemistry, 3rd Edn. New York, NY: Academic.

Seitzinger, S. P., and Kroeze, C. (1998). Global distribution of nitrous oxide production and $\mathrm{N}$ inputs in freshwater and coastal marine ecosystems. Glob. Biogeochem. Cycles 12, 93-113. doi: 10.1029/97GB03657

Starry, O. S., Valett, H. M., and Schreiber, M. E. (2005). Nitrification rates in a headwater stream: influence of seasonal variation in $\mathrm{C}$ and $\mathrm{N}$ supply. J. N. Am. Benthol. Soc. 24, 753-768. doi: 10.1899/05-015.1

Strauss, E. A., and Lamberti, G. A. (2002). Effect of organic carbon quality on microbial decomposition of DOC and nitrification rates in stream sediments. Freshw. Biol. 47, 65-74. doi: 10.1046/j.1365-2427.2002.00776.x

Strauss, E. A., Mitchell, N. L., and Lamberti, G. A. (2002). Factors regulating nitrification in aquatic sediments: effects of organic carbon, nitrogen availability, and pH. Can. J. Fish. Aquat. Sci. 59, 554-563. doi: 10.1139/f02-032

Stream Solute Workshop (1990). Concepts and methods for assessing solute dynamics in stream ecosystems: concepts and methods for assessing solute dynamics in stream ecosystems. J. N. Am. Benthol. Soc. 9, 95-119. doi: $10.2307 / 1467445$

Syakila, A., and Kroeze, C. (2011). The global nitrous oxide budget revisited. Greenhouse Gas Meas. Manage. 1, 17-26. doi: 10.3763/ghgmm.2010.0007

Thouin, J. A., Wollheim, W. M., Vörösmarty, C. J., Jacobs, J. M., and McDowell, W. $\mathrm{H}$. (2009). The biogeochemical influence of $\mathrm{NO}_{3}^{-}$, dissolved $\mathrm{O}_{2}$, and dissolved organic C on stream $\mathrm{NO}_{3}^{-}$uptake. J. N. Am. Benthol. Soc. 28, 894-907. doi: $10.1899 / 08-183.1$

van Groenigen, J. W., Huygens, D., Boeckx, P., Kuyper T. W., Lubbers, I. M., Rutting, T., et al. (2015). The soil N cycle: new insights and key challenges. Soil. 1, 235-256. doi: 10.5194/soil-1-235-2015

Vellidis, G., Lowrance, R., Gay, P., and Hubbard, R. K. (2003). Nutrient transport in a restored riparian wetland. J. Environ. Qual. 32, 711-726. doi: $10.2134 /$ jeq 2003.7110

Vitousek, P. M., Aber, J. D., Howarth, R. W., Likens, G. E., Matson, P. A., Schindler, D. W., et al. (1997). Human alteration of the global nitrogen cycle: sources and consequences. Ecol. Appl. 7, 737-750. doi: 10.1890/1051-0761(1997)007[0737:HAOTGN]2.0.CO;2

Wanek, W., Mooshammer, M., Blochl, A., Hanreich, A., and Richter, A. (2010). Determination of gross rates of amino acid production and immobilization in decomposing leaf litter by a novel $15 \mathrm{~N}$ isotope pool dilution technique. Soil Biol. Biochem. 42, 1293-1302. doi: 10.1016/j.soilbio.2010.04.001

Webb, J. R., Hayes, N. M., Simpson, G. L., Leavitt, P. R., Baulch, H. M., and Finlay, K. (2019). Widespread nitrous oxide undersaturation in farm waterbodies creates an unexpected greenhouse gas sink. Proc. Natl. Acad. Sci. U.S.A. 116, 9814-9819. doi: 10.1073/pnas.1820389116
Webster, J. R., Mulholland, P. J., Tank, J. L., Valett, H. M., Dodds, W. K., Peterson, B. J., et al. (2003). Factors affecting ammonium uptake in streams - an inter-biome perspective. Freshw. Biol. 48, 1329-1352. doi: 10.1046/j.1365-2427.2003.01094.x

Wollheim, W. M., Bernal, S., Burns, D. A., Czuba, J. A., Driscoll, C. T., Hansen, A. T., et al. (2018). River network saturation concept: factors influencing the balance of biogeochemical supply and demand of river networks. Biogeochemistry 141, 503-521. doi: 10.1007/s10533-018-0488-0

Wrage, N., Velthof, G. L., van Beusichem, M. L., and Oenema, O. (2001). Role of nitrifier denitrification in the production of nitrous oxide. Soil Biol. Biochem. 33, 1723-1732. doi: 10.1016/S0038-0717(01)00096-7

Wymore, A. S., Brereton, R. L., Ibarra, D., Maher, K., and McDowell, W. H. (2017). Critical zone structure controls concentration-runoff relationships in watersheds draining a tropical montane forest. Water Resour. Res. 53. doi: 10.1002/2016WR020016

Wymore, A. S., Coble, A. A., Rodríguez-Cardona, B., and McDowell, W. H. (2016). Nitrate uptake across biomes and the influence of elemental stoichiometry: a new look at LINX II. Glob. Biogeochem. Cycles 30. doi: 10.1002/2016GB005468

Wymore, A. S., Leon, M. C., Shanley, J. B., and McDowell, W. H. (2019). Hysteretic response of solutes and turbidity at the event scale across forested tropical montane watersheds. Front. Earth Sci.: Biogeosci. 7:126. doi: 10.3389/feart.2019.00126

Wymore, A. S., Rodríguez-Cardona, B., and McDowell, W. H. (2015). Direct response of dissolved organic nitrogen to nitrate availability in headwater streams. Biogeochemistry 121, 1-10. doi: 10.1007/s10533-015-0153-9

Zhu, G., Jetten, M. S., Kuschk, P., Ettwig, K. F., and Yin, C. (2010). Potential roles of anaerobic ammonium and methane oxidation in the nitrogen cycle of wetland ecosystems. Appl. Environ. Microbiol. 86, 1043-1055. doi: 10.1007/s00253-010-2451-4

Zhu, G., Wang, S., Wang, W., Wang, Y., Zhou, L., Jiang, B., et al. (2013). Hotspots of anaerobic ammonium oxidation at land-freshwater interfaces. Nat. Geosci. 6, 103-107. doi: 10.1038/ngeo1683

Zhu, G., Xia, C., Shanyun, W., Zhou, L., Liu, L., and Zhao, S. (2015). Occurrence, activity, and contribution of anammox in some freshwater extreme environments. Environ. Microbiol. Rep. 7, 961-969. doi: $10.1111 / 1758-2229.12341$

Conflict of Interest: The authors declare that the research was conducted in the absence of any commercial or financial relationships that could be construed as a potential conflict of interest.

Copyright (C) 2019 Wymore, Rodríguez-Cardona, Herreid and McDowell. This is an open-access article distributed under the terms of the Creative Commons Attribution License (CC BY). The use, distribution or reproduction in other forums is permitted, provided the original author(s) and the copyright owner(s) are credited and that the original publication in this journal is cited, in accordance with accepted academic practice. No use, distribution or reproduction is permitted which does not comply with these terms. 